WSRC-TR-2001-00255

\title{
Heat Transfer Calculations For Normal Operations Of A Fixed CST Bed Column
}

Si Young Lee

Westinghouse Savannah River Company

Savannah River Site

Aiken, SC 29808

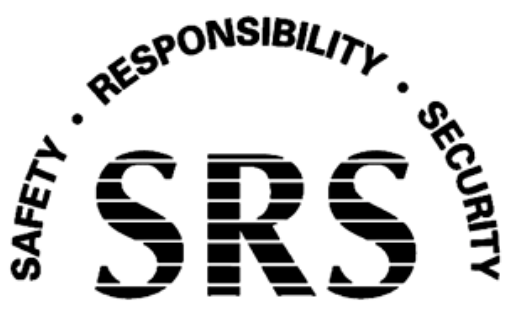


This document was prepared in conjunction with work accomplished under Contract No.

DE-AC09-96SR18500 with the U.S. Department of Energy.

\section{DISCLAIMER}

This report was prepared as an account of work sponsored by an agency of the United States Government. Neither the United States Government nor any agency thereof, nor any of their employees, makes any warranty, express or implied, or assumes any legal liability or responsibility for the accuracy, completeness, or usefulness of any information, apparatus, product or process disclosed, or represents that its use would not infringe privately owned rights. Reference herein to any specific commercial product, process or service by trade name, trademark, manufacturer, or otherwise does not necessarily constitute or imply its endorsement, recommendation, or favoring by the United States Government or any agency

thereof. The views and opinions of authors expressed herein do not necessarily state or reflect those of the United States Government or any agency thereof.

This report has been reproduced directly from the best available copy.

Available for sale to the public, in paper, from: U.S. Department of Commerce, National Technical Information Service, 5285 Port Royal Road, Springfield, VA 22161, phone: (800)

553-6847, fax: (703) 605-6900, email: orders@ntis.fedworld.gov online ordering: http://www.ntis.gov/ordering.htm

Available electronically at http://www.doe.gov/bridge

Available for a processing fee to U.S. Department of Energy and its contractors, in paper, from: U.S. Department of Energy, Office of Scientific and Technical Information, P.O. Box 62, Oak Ridge, TN 37831-0062, phone: (865 ) 576-8401, fax: (865) 576-5728, email: reports@ adonis.osti.gov 
WSRC-TR-2001-00255

KEYWORDS:

Heat Transfer Model

Numerical Approach

Porous Media

Natural Convection

Heat Convection

RETENTION - Permanent

\section{Heat Transfer Calculations For Normal Operations Of A Fixed CST Bed Column}

SAVANNAH RIVER TECHNOLOGY CENTER

Si Young Lee

Publication Date: May, 2001

Westinghouse Savannah River Company

Savannah River Site

Aiken, SC 29808

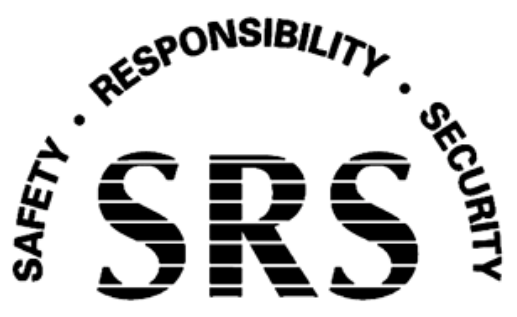

SAVANNAH RIVER SITE

Prepared for the U.S. Department of Energy under Contract No. DE-AC09-96SR18500 
(This Page Intentionally Left Blank) 
DOCUMENT: WSRC-TR-2001-00255

TITLE: Heat Transfer Calculations For Normal Operations Of A Fixed CST Bed Column

\section{APPROVALS}

Si Y. Lee, Author (EM\&S Group/ SRTC)

Date:

Date:

Richard A. Dimenna, Technical Review (EM\&S Group/ SRTC)

Date:

Jeff A. Pike, Customer (HLW Process Engineering)

Richard E. Edwards, Jr., Manager (HLW Process Engineering)

Date:

Date:

Joe T. Carter, Director of Engineering (Salt Waste Disposition Facility)

Date:

Dennis W. Wester, TFA CST System Lead (Pacific Northwest National Laboratory)

Cynthia P. Holding-Smith, Manager (EM\&S Group/SRTC)

Date:

Steve T. Wach, Manager (EDS/SRTC)

Date: 
(This Page Intentionally Left Blank)

-iv- 


\section{Table of Contents}

List of Figures vii

List of Tables viii

Nomenclature $\quad$ ix

$\begin{array}{ll}\text { Abstract } & 1\end{array}$

1 Introduction 2

2. Modeling Approach and Analysis $\quad 3$

2.1 Temperature Distributions inside Spherical Solid Particle with Heat Generation Source ................................................................................... 4

2.2 Heat Transfer Analysis for Fluid-Particle System in Porous Bed.......................... 7

2.2.1 Heat Transfer between Stagnant Fluids and Single Particle (Case-I) ............... 7

2.2.2 Heat Transfer of a Single Particle under Forced Convection Cooling (Case-II) .............................................................................................. 8

2.2.3 Particle-Fluid Heat Transfer for Fixed CST Bed under Forced Convection (Case-III) ............................................................................... 9

2.2.4 CFD Approach for Heat transfer Analysis for CST Column (Case-III)............. 10

3. Results and Discussions 15

4. Conclusions 21

5. References 23 
(This Page Intentionally Left Blank) 


\section{List of Figures}

Figure 1. Schematic illustrations of CST packed bed column under normal flow conditions

Figure 2. Heat transfer for a single particle with volumetric heat source q"'. 6

Figure 3. Heat transfer for a single particle with heat generation in stagnant liquid medium (Case-I).

Figure 4. Heat transfer for a fixed single particle with heat generation source in moving fluid (Case-II)

Figure 5. Heat transfer for a fixed porous bed with heat generation source under forced convection cooling condition (Case-III)

Figure 6. Computational model for the heat transfer in CST column using CFD approach.

Figure 7. Computational meshes for the CST heat transfer calculations 14

Figure 8. Theoretical approach of one-dimensional energy transport for the CST column with adiabatic wall boundary.

Figure 9. Fluid velocity vector plot in the porous region of the CST column 18

Figure 10. Temperature contour plots for the fluid and solid particle zones of the CST column cooled by natural convection at the wall

Figure 11. Radial interstitial velocity distributions at inlet and exit planes of the CST column

Figure 12. Comparison of radial temperature distributions for fluid and solid at the exit of the CST column

Figure 13. Qualitative results of key operating parameters as function of radial position at the exit of the CST column with uniform volumetric heat source....

Figure 14. Comparison of axial temperature distributions along the flow direction 


\section{List of Tables}

Table 1. Status of heat transfer analysis for a fixed porous bed of a fully-loaded CST column.

Table 2. Nominal design conditions used for the present analysis. ...................................

Table 3. Modeling approaches taken for the present analysis.......................................

Table 4. Material, thermal, and transport properties for the CST column heat transfer

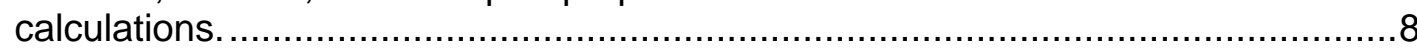

Table 5. Summary for the heat transfer calculation results for the three cases considered in the analysis.

Table 6. Comparison of the one-dimensional theoretical predictions with the CFD model results for heat removal capability of the CST column.

Table 7. Comparison of maximum temperatures predicted by the CFD model of the CST column. 


\section{Nomenclature}

$a_{p}=$ surface area of a single particle $\left(\mathrm{m}^{2}\right)$

$A=$ total surface area $\left(\mathrm{m}^{2}\right)$

$\mathrm{Cp}=$ specific heat $(\mathrm{J} / \mathrm{kgK})$

$\mathrm{d}=\operatorname{diameter}(\mathrm{m})$

$\mathrm{g}=$ gravity $\left(\mathrm{m} / \mathrm{sec}^{2}\right)$

$\mathrm{h}=$ enthalpy $(\mathrm{J} / \mathrm{kg})$ or heat transfer coefficient $\left(\mathrm{W} / \mathrm{m}^{2} \mathrm{~K}\right)$

$\mathrm{k}=$ thermal conductivity $(\mathrm{W} / \mathrm{mK})$

$\mathrm{H}=$ column height or characteristic length $(\mathrm{m})$

$\mathrm{n}=$ total number of particles contained in the column

$\mathrm{Nu}=$ Nusselt number, hd/k

$\operatorname{Pr}=$ Prandtl number, $\mu \mathrm{C}_{\mathrm{p}} / \mathrm{k}$

$q^{\prime \prime}=$ heat flux $\left(\mathrm{W} / \mathrm{m}^{2}\right)$

$q^{\prime \prime \prime}=$ heat generation source per unit volume $\left(\mathrm{W} / \mathrm{m}^{3}\right)$

$\mathrm{Q}_{\mathrm{h}}=$ heat transfer rate $(\mathrm{W})$

$r=$ radial distance from the center of CST column $(\mathrm{m})$

$\mathrm{R}=$ column radius $(\mathrm{m})$

$\mathrm{Re}=$ Reynolds number, $\mathrm{d} \rho \mathrm{u} / \mu$

$\mathrm{T}=$ temperature $\left({ }^{\circ} \mathrm{C}\right)$

$\mathrm{u}=$ superficial velocity in porous media $(\mathrm{m} / \mathrm{sec})$

$\mathrm{v}=$ local interstitial velocity $(\mathrm{m} / \mathrm{sec})$

$\mathrm{V}=$ volume $\left(\mathrm{m}^{3}\right)$

$\mathrm{x}=$ local position along the $\mathrm{x}$-direction under Cartesian coordinate system

$y=$ local position along the $y$-direction under Cartesian coordinate system

$z=$ vertical position along the bulk flow direction

\section{Greek}

$\alpha=$ particle surface area per unit volume $\left(\mathrm{m}^{-1}\right)$

$\rho=$ density $\left(\mathrm{kg} / \mathrm{m}^{3}\right)$

$\Delta=$ difference

$\mu=$ dynamic viscosity $\left(\mathrm{N} \mathrm{sec} / \mathrm{m}^{2}\right)$

$v=$ kinematic viscosity $\left(\mathrm{m}^{2} / \mathrm{sec}\right)$ 


\section{Subscript}

avg = average

Bed $=$ bed

eff $=$ effective

exit $=$ column exit

$\mathrm{f}=$ bulk fluid

$\mathrm{i}=$ initial or interface

inlet $=$ column inlet

$\mathrm{m}=$ center of a single particle in a fully-loaded CST column

$\max =$ maximum

$\mathrm{p}=$ particle

$\mathrm{s}=$ surface of a solid particle

w or wall $=$ column wall

$\infty=$ ambient 


\section{Abstract}

In support of the crystalline silicotitanate (CST) ion exchange project of High-Level Waste (HLW) Process Engineering, heat transfer calculations have been made for a fully-loaded CST column during abnormal and normal operating conditions.

The modeling and calculations have been performed using theoretical and computational heat transfer approaches. The previous heat transfer calculations [Ref. 1] estimated conservative heat transfer rates for the column under no-flow conditions. For the present analysis, three basic cases were theoretically considered to estimate sensitivities of temperature distributions with respect to the configurations of fluidparticle systems. Steady-state temperature responses to a uniform heat source in a fixed bed were estimated using the literature data. A theoretical, one-dimensional approach was taken by considering overall energy balance for the CST column. A computational heat transfer approach was also taken to estimate detailed flow distribution effects on the temperature profiles of a fixed bed CST column. In this approach, the commercial finite volume code, CFX [Ref. 4], was used to create a prototypic geometry file under a non-orthogonal mesh environment. In this case, a node-mapping technique was developed to consider convection effect in the energy equation due to the fluid motion in porous media with a heat source present in the solid particle region.

All the analysis results demonstrate that about $21 \mathrm{gpm}$ process flow of the normally operating CST column provides adequate heat removal from a fully-loaded fixed bed column containing $94 \mathrm{~W} / \mathrm{ft}^{3}$ heat source. The results of a single particle model show that there are negligible temperature differences between the center and surface of a single solid particle for the conditions considered here. From the analysis of fluidparticle systems, the temperature gradient at the particle-fluid interface of a looselypacked bed is found to be much lower than that of a packed bed from the experimental data available in the literature. For the normal flow conditions of a fixed CST bed, average temperature difference between the particle surface and the bulk fluid medium is found to be less than $0.5^{\circ} \mathrm{C}$.

The theoretical and simulation results show that about $30^{\circ} \mathrm{C}$ of average fluid temperature is reached at the exit plane of the column when a fully-loaded CST column has a $94 \mathrm{~W} / \mathrm{ft}^{3}$ heat source and a $25^{\circ} \mathrm{C}$ inlet temperature under the normal flow condition. The simulation results show that a maximum local temperature of about $34^{\circ} \mathrm{C}$ is reached at the exit of the bed column. In this case, the fluid temperature is about $1{ }^{\circ} \mathrm{C}$ lower than the particle temperature for the operating conditions of the CST column when the column wall is cooled by natural convection.

From the sensitivity study of the CST design parameters, it was found that whether the column is loosely-packed or densely-packed is a key parameter associated with the coolability of a fully-loaded CST column under normal flow conditions since bed porosity is closely related to the effective energy transport of the column. In addition, the results computed by the simulation model were verified by the theoretical results.

The analysis results will provide quantitative information associated with the process heat control and management of the CST column base design. 


\section{Introduction}

The crystalline silicotitanate (CST) ion exchange process treats high-level radioactive waste for feed to the saltstone facility to be made into grout. Through this process, radionuclides such as strontium, plutonium, and uranium are removed by the monosodium titanate (MST) addition, and then cesium nuclide from the salt supernate solution is absorbed into the CST bed.

An ion exchange column loaded with the CST will generate significant heat from radioactive decay. The CST material in the bed column is being used as an inorganic ion-exchange media to remove cesium nuclide from the supernatant stored in the highlevel radioactive waste tanks at the Savannah River Site (SRS). The supernatant is primarily a mixture of aqueous sodium nitrate and sodium hydroxide with smaller concentrations of other species. Sorption of the cesium from the supernatant results in concentrating the cesium into the volume of the CST. In this situation, the cesium becomes a source of significant thermal energy in the column.

If engineering designs of the CST sorption column can not handle this thermal load, hot spots may develop locally within the column and degrade the performance of the ionexchange process. Thus, heat transfer analyses for a fully-loaded CST column have been performed for transient no-flow and steady-state normal operation conditions as shown in Table 1. In the previous calculations [Ref. 1], a conservative approach was taken. That is, a conduction-dominant cooling mode was considered for loss of flow or no flow conditions through the CST column assuming convection effect to be negligible. The previous report presented transient thermal responses to no-flow conditions of a fully-loaded CST column for various modeling boundary and design conditions.

The objective of the present work is to compute temperature distributions across the column when there is steady flow of salt solution through the CST column under normal conditions of the process operations. In this situation, the High-Level Waste (HLW) customer [Ref. 2] requested that the calculations should be conservative in that the model results would show the maximum temperatures achievable by the CST design configurations under normal flow conditions. Schematic diagram for the CST column system is illustrated in Fig. 1.

The analysis results will be used to evaluate the fluid temperature distributions and the process component temperatures within the ion exchange system. This information will also assist in the system base design.

Table 1. Status of heat transfer analysis for a fixed porous bed of a fully-loaded CST column.

\begin{tabular}{|c|c|c|}
\hline System Conditions & Modeling Approaches & Doc. of Analysis Results \\
\hline Loss of process flow & $\begin{array}{c}\text { Transient analysis for no-flow } \\
\text { conditions }\end{array}$ & Done [Ref. 1] \\
\hline Normal operations & $\begin{array}{c}\text { Steady-state analysis for } \\
\text { 21gpm normal flow }\end{array}$ & Present analysis \\
\hline
\end{tabular}




\section{Modeling Approach and Analysis}

For the CST operation, the column bed requires the dimensions of $16 \mathrm{ft}$ long and $5 \mathrm{ft}$ diameter to maintain the designed process rates. A fully-loaded column may generate as much as about $6 \times 10^{6} \mathrm{Ci}$ radioactivity. This highly concentrated radioactive source will contain a significant amount of heat load in the column, which corresponds to about $94 \mathrm{~W} / \mathrm{ft}^{3}$ of volumetric heat source based on total volume of the bed.

The results of the present analysis will determine if process fluid flow through the column under normal operating conditions provides adequate heat removal from a fullyloaded fixed bed CST column containing the decay heat source. Detailed reference design and normal operating conditions are shown in Table 2. Under this normal flow situation of the CST column, there are some concerns about what is maximum local temperature difference between the CST particle and its surrounding fluid for the steady-state normal flow conditions of the fully-loaded column and how effectively the column cools down along the axial flow direction under the current design configurations.

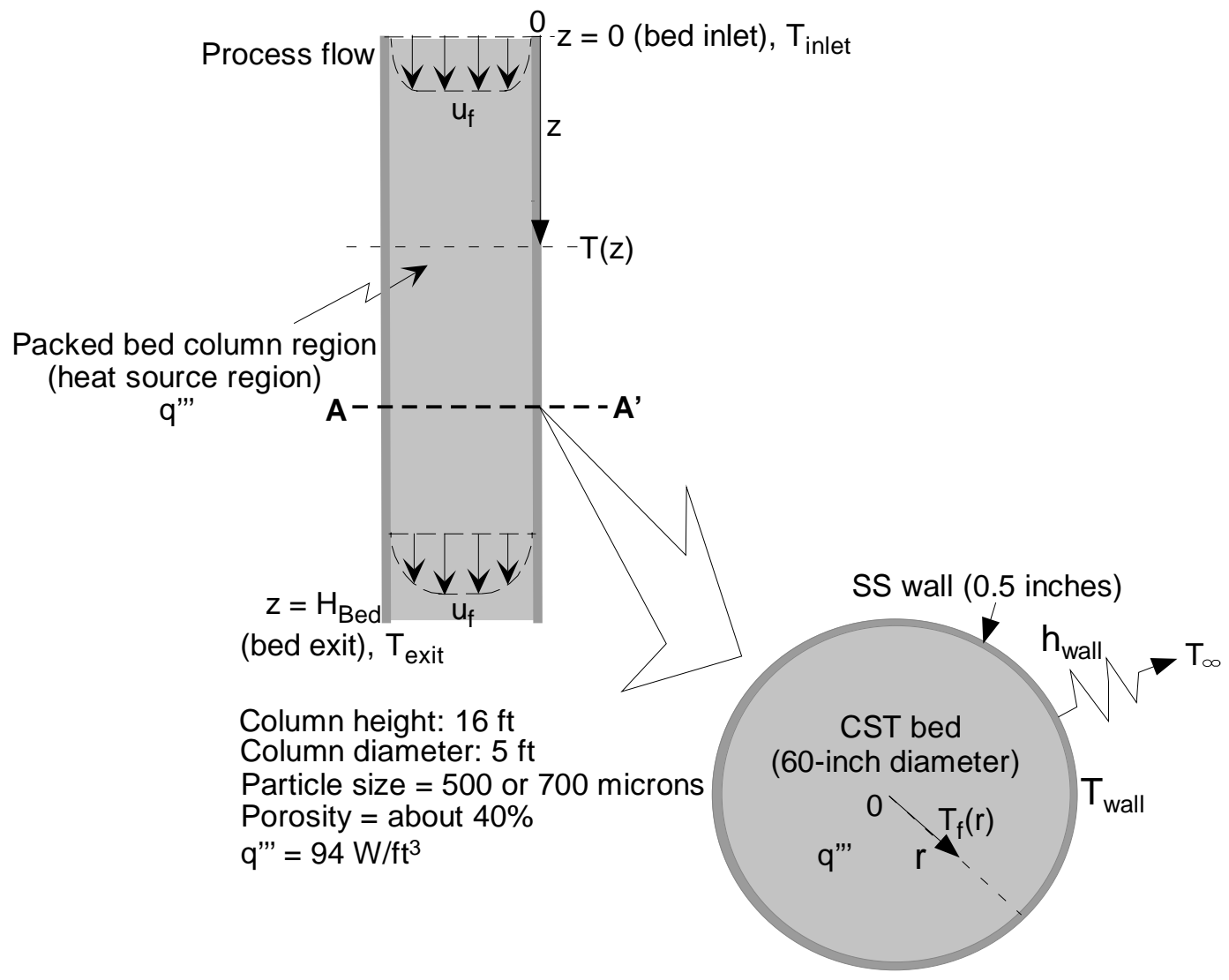

(A-A' cross-sectional plane)

Figure 1. Schematic illustrations of CST packed bed column under normal flow conditions 
For the present analysis, theoretical and computational approaches were taken to calculate temperature distributions for the modeling domain of the CST column using the literature data. In this case, one-dimensional steady-state overall energy balance for the column domain was considered to calculate temperature profiles for the particle-fluid systems. A three-dimensional computational fluid dynamics (CFD) approach was taken to examine the non-uniform flow effect on local temperature distributions of a fullyloaded CST column. In this approach, the commercial finite volume code, CFX [4], was used to create prototypic geometry file under non-orthogonal mesh environment.

The analysis consists of two major parts as presented in Table 3 . One part is to estimate maximum temperature difference between the center and surface of a single particle assuming that every CST particle has perfectly spherical shape with uniform volumetric heat source. The second part is to perform heat transfer analysis for the fluid-particle system in a porous bed after evaluating the internal temperature gradient for a single CST particle with heat generation source from the first part. In the second part of the analysis, the model considers three basic cases with different boundary conditions to investigate how sensitive the temperature profiles for porous bed with uniform heat source are to various conditions of the particle-fluid system in a porous bed.

The CST column system to be analyzed here is illustrated in Fig. 1. The model geometry was created using the body-fitted coordinate system and structured multiblock grids in the CFD preprocessing environment. For the heat transfer analysis, the reference design conditions were considered as shown in Table 2. Spherical CST particles (about 500-micron or 700-micron diameter) are packed inside a column of stainless steel cylinder that is $16 \mathrm{ft}$ high and $5 \mathrm{ft}$ diameter along the 0.5 -inch thick wall. In the present analysis, the resistance of heat transfer across the column wall was neglected from the previous results [Ref. 1]. The porosity of the CST packed bed was assumed to be about $40 \%$ for conservative estimations of temperature profiles within the column although the porosity the customer provided [Ref. 2] was higher than $40 \%$. In the ORNL work, the density of the salt solution was estimated to be about $1255 \mathrm{~kg} / \mathrm{m}^{3}$ considering that density of CST solid is $2,056 \mathrm{~kg} / \mathrm{m}^{3}$. Thermal conductivity of the solution was used as $0.15538 \mathrm{~W} / \mathrm{mK}$ (evaluated at $25^{\circ} \mathrm{C}$ temperature). Detailed material and thermal properties used in the analysis are shown in Table 4.

\section{1 Temperature distributions inside spherical solid particle with heat generation source}

Internal temperature distributions of a single solid particle can be calculated theoretically for uniformly distributed heat source. Steady-state governing equation for the conduction-controlled solid medium with uniform volumetric heat source q"', as shown in Fig. 2, can be written under spherical coordinate system as

$$
\frac{1}{r^{2}}\left(\frac{d}{d r} r^{2} \frac{d T(r)}{d r}\right)+\frac{q^{\prime \prime}}{k_{f}}=0
$$

where $\mathrm{k}_{\mathrm{f}}$ is thermal conductivity of the solid sphere. 
Table 2. Reference design conditions used for the present analysis.

\begin{tabular}{|c|c|}
\hline Parameters & Conditions \\
\hline $\begin{array}{c}\text { Bed column dimensions } \\
\left(\mathrm{d}_{\text {Bed }} \times \mathrm{H}_{\text {Bed }}\right)\end{array}$ & $5 \mathrm{ft}$ diameter $\times 16 \mathrm{ft}$ high \\
\hline Particle diameter $\left(\mathrm{d}_{\mathrm{p}}\right)$ & $500^{*}$ and 700 microns \\
\hline Bed porosity $(\varepsilon)$ & $0.40^{* *}$ \\
\hline $\begin{array}{c}\text { Salt solution temperature at inlet } \\
\left(\mathrm{T}_{\text {inlet }}\right)\end{array}$ & $25^{\circ} \mathrm{C}$ \\
\hline $\begin{array}{c}\text { Salt solution flowrate } \\
\text { Superficial fluid velocity }(\mathrm{u})\end{array}$ & $21 \mathrm{gpm}$ \\
\hline $\begin{array}{c}\text { Heat generation rate per bed } \\
\left.\text { volume ( } \mathrm{q}^{\prime \prime \prime} \text { Bed }\right)\end{array}$ & $9.26 \times 10^{-4} \mathrm{~m} / \mathrm{sec}$ \\
\hline
\end{tabular}

Note: *500-micron particle is used for the normal operation analysis of a fully-loaded CST column.

** $40 \%$ porosity (instead of $50 \%$ ) is used for a conservative approach

Table 3. Modeling approaches taken for the present analysis.

\begin{tabular}{|c|c|c|c|}
\hline $\begin{array}{l}\text { Analysis } \\
\text { Domain }\end{array}$ & $\begin{array}{c}\text { Analysis } \\
\text { Cases }\end{array}$ & $\begin{array}{l}\text { Modeling } \\
\text { Approaches }\end{array}$ & Primary Purposes \\
\hline $\begin{array}{l}\text { Single Solid } \\
\text { Particle }\end{array}$ & --- & Theoretical & $\begin{array}{l}\text { To estimate maximum temperature difference } \\
\text { for a single particle domain containing heat } \\
\text { source }\end{array}$ \\
\hline \multirow{4}{*}{$\begin{array}{l}\text { Particle- } \\
\text { Fluid } \\
\text { System }\end{array}$} & Case-I & Theoretical & $\begin{array}{l}\text { To evaluate heat transfer for a single sphere } \\
\text { containing heat source in stagnant bulk fluid } \\
\text { (simulated as loosely-packed bed) }\end{array}$ \\
\hline & Case-II & Theoretical & $\begin{array}{l}\text { To evaluate heat transfer for a single sphere } \\
\text { containing heat source in a flowing fluid } \\
\text { (simulated as a loosely-packed bed) }\end{array}$ \\
\hline & \multirow{2}{*}{ Case-III } & Theoretical & $\begin{array}{l}\text { To estimate heat transfer capability for a } \\
\text { closely-packed and fixed bed in a flowing fluid } \\
\text { using one-dimensional energy transport }\end{array}$ \\
\hline & & $\begin{array}{l}\text { Numerical } \\
\text { (CFD) }\end{array}$ & $\begin{array}{l}\text { To estimate heat transfer capability for a fixed } \\
\text { fully-loaded CST column in a flowing fluid } \\
\text { using multi-dimensional momentum and } \\
\text { energy transport }\end{array}$ \\
\hline
\end{tabular}


Equation (1) is imposed by the boundary conditions at the center of the sphere $(r=0)$.

$T(r=0)=T_{m}$ and $\left.\frac{d T}{d r}\right|_{r=0}=0$

Spatial temperature distributions within the solid region of spherical particle can be determined by using eqs. (1) and (2) in terms of heat generation rate per particle volume (q"') and thermal conductivity of the particle.

$T(r)=T_{m}-\left(\frac{q^{\prime,}}{6 k_{p}}\right) r^{2}$

Maximum temperature difference between the center and surface of spherical solid can be obtained in terms of volumetric heat source as

$$
\left(T_{m}-T_{s}\right)=\left(\frac{q^{\prime \prime},}{24 k_{p}}\right)\left(d_{p}\right)^{2} .
$$

Mathematical notations used in eq. (4) are described in Fig. 2.

When bed porosity and particle surface temperature are assumed to be uniform, maximum temperature difference between the center and surface of spherical solid can be obtained in terms of volumetric heat source based on bed volume ( $q_{\text {Bed }}$ ') as

$$
\left(T_{m}-T_{s}\right)=\left(\frac{q_{\text {Bed }}{ }^{\prime \prime},}{24 k_{p}(1-\varepsilon)}\right)\left(d_{p}\right)^{2} \text {. }
$$

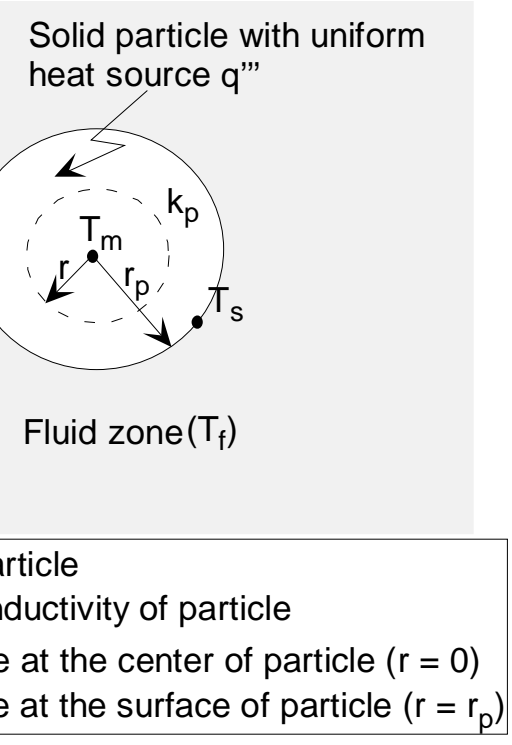

Figure 2. Heat transfer for a single particle with volumetric heat source q"' 


\subsection{Heat Transfer Analysis for Fluid-Particle System in Porous Bed}

\subsubsection{Heat Transfer between Stagnant Fluids and Single Particle (Case-I)}

Transfer of heat from sphere to the stagnant surrounding medium has been treated by conduction theoretically as shown in Fig. 3. Rudenberg (1925) showed that the exchange rate $Q_{h}$ of heat by conduction between a sphere acting as a heat source and its surroundings can be represented by the relation

$Q_{h}=2 \pi d_{p} k_{f}\left(1+\frac{d_{p}}{4 z}\right)^{-1}\left(T_{s}-T_{f}\right)$

In eq. (5) $T_{s}$ represents the surface temperature of a spherical particle and $T_{f}$ the temperature of the surroundings measured at large distance $z$ from the spherical solid relative to the diameter of the sphere $\left(d_{p}\right) . k_{f}$ is thermal conductivity of the surrounding fluid in eq. (5). In terms of the conventional heat transfer coefficient $h_{f}$ defined by the relation

$Q_{h}=h_{f} a_{p}\left(T_{s}-T_{f}\right)=\left(\pi d_{p}^{2}\right) h_{f}\left(T_{s}-T_{f}\right)$

When $\mathrm{z}$ is much larger than $d_{\mathrm{p}}$, eq. (5) becomes

$Q_{h}=2 \pi d_{p} k_{f}\left(T_{s}-T_{f}\right)$

From the comparison between eq. (6) and eq. (7), Nusselt number can be obtained in terms of spherical diameter $d_{p}$.

$N u=\frac{d_{p} h_{f}}{k_{f}}=2$

When CST particle size is 500 microns, heat transfer coefficient $h_{f}$ at the surface of the CST particle is calculated as $2720 \mathrm{~W} / \mathrm{m}^{2} \mathrm{~K}$ for thermal conductivity of the salt solution provided in Table 4. In this case temperature difference between the surface of particle and stagnant bulk fluid can be computed by eq. (9) for given particle size and volumetric heat source of the bed column.

$$
\left(T_{s}-T_{f}\right)=\frac{Q_{h}}{h_{f} a_{p}}=\frac{q_{B e d}, '}{h_{f} \alpha_{p}(1-\varepsilon)}
$$

In eq. (9) the ratio $\alpha_{p}$ of the area to volume of a single particle becomes

$$
\alpha_{p}=\frac{a_{p}}{V_{p}}=\frac{6}{d_{p}}
$$




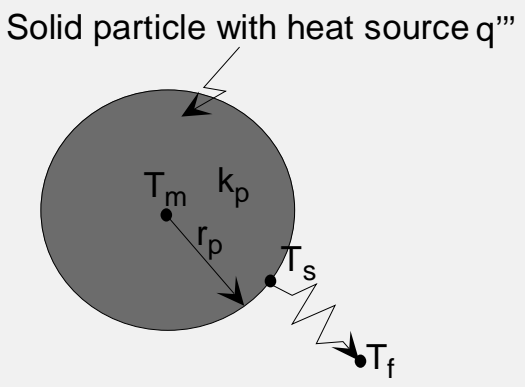

Stagnant fluid zone

Figure 3. Heat transfer for a single particle with heat generation in stagnant liquid medium (Case-I)

Table 4. Material, thermal, and transport properties for the CST column heat transfer calculations.

\begin{tabular}{|c|c|c|c|c|}
\hline Material & $\begin{array}{c}\text { Thermal conductivity } \\
(\mathrm{W} / \mathrm{mK})\end{array}$ & $\begin{array}{c}\text { pecific heat } \\
(\mathrm{J} / \mathrm{kgK})\end{array}$ & $\begin{array}{c}\text { Density } \\
(\mathrm{kg} / \mathrm{m} 3)\end{array}$ & $\begin{array}{c}\text { Viscosity } \\
(\mathrm{cp})\end{array}$ \\
\hline CST [Ref. 2] & $0.13968+6.2800 \times 10^{-4} \mathrm{~T}^{*}$ & 1052.3 & 2056.3 & -- \\
\hline Salt Solution [Ref. 2] & 0.68 & 3630.0 & 1255.4 & $2.0^{* *}$ \\
\hline Stainless steel [Ref. 17] & 17.30 & 486.0 & 7800.0 & --- \\
\hline
\end{tabular}

Note: ${ }^{*} \mathrm{~T}$ in ${ }^{\circ} \mathrm{C}$ (evaluated at $25^{\circ} \mathrm{C}$ temperature)

${ }^{* *}$ Ref. 10

\subsubsection{Heat Transfer of a Single Particle under Forced Convection Cooling (Case-II)}

Forced convection heat transfer for a single sphere submerged in moving fluids can be evaluated by using empirical correlation available in the literature. This case is also designed to simulate the heat transfer of particles in loosely-packed bed or dilute suspension systems. The situation is illustrated in Fig. 4. Forced convection heat transfer for this situation is given by the literature [Kramers, 1946].

$N u=2.0+1.3 \operatorname{Pr}^{0.15}+0.66 \operatorname{Pr}^{0.31} \operatorname{Re}_{p}{ }^{0.5}$

In eq. (11) Reynolds number $\left(R e_{p}\right)$ is evaluated in term of particle diameter $\left(d_{p}\right)$ and superficial fluid velocity $\left(u_{f}\right)$.

$R e_{p}=\frac{\rho_{f} d_{p} u_{f}}{\mu_{f}}$

For the present $21 \mathrm{gpm}$ flow condition and 500-micron particle size, the Reynolds number $\left(R e_{p}\right)$ is about 0.23 . In this situation, heat transfer coefficient $h_{f}$ is computed by 
eq. (11) using material and thermal properties given in Table 4. That is, $h_{f}=6138.9$ $\left(\mathrm{W} / \mathrm{m}^{2} \mathrm{~K}\right)$. In this case temperature drop across the interface of particle surface and flowing fluid can calculated by eq. (9).

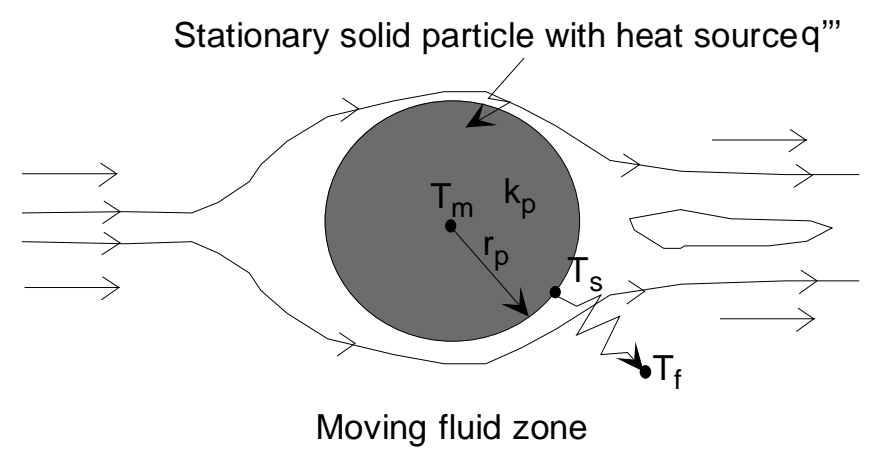

Figure 4. Heat transfer for a fixed single particle with heat generation source in moving fluid (Case-II)

\subsubsection{Particle-Fluid Heat Transfer for Fixed CST Bed under Forced Convection (Case-III)}

The heat transfer between beds of particles and fluid flowing through the interstices is evaluated for steady-state normal operating conditions of the CST bed column as shown in Fig. 5. Heat source per bed volume is about $3319.6 \mathrm{~W} / \mathrm{m}^{3}$, which is equivalent to 94 $\mathrm{W} / \mathrm{ft}^{3}$. For normal operating conditions, superficial velocity is about $0.7 \mathrm{~mm} / \mathrm{sec}$ corresponding to $21 \mathrm{gpm}$ flow in $5 \mathrm{ft}$ diameter CST column. In this situation the Reynolds number is about 0.23 for 500 micron particle diameter. Gunn and Souza (1974) made a collection of experimental results of the particle Nusselt number group at low Reynolds numbers. Nusselt number estimated by their empirical results was used for the present analysis. That is, particle Nusselt number (Nu) was found to be about 0.001 , resulting in $h_{f}=1.36 \mathrm{~W} / \mathrm{m}^{2} \mathrm{~K}$ for the present conditions. Temperature difference between the particle surface and its surrounding fluid was computed by the conventional heat transfer relation.

$$
\begin{aligned}
(\Delta T)_{\text {Bed }} & =\left(T_{s}-T_{f}\right)_{\text {Bed }}=\left(\frac{Q_{h}}{h_{f} A_{p}}\right) \\
& =\frac{1}{h_{f}}\left(\frac{V_{\text {Bed }}}{A_{p}}\right) q_{B e d},, '=\frac{q_{B e d},,}{h_{f} \alpha_{B e d}}
\end{aligned}
$$

In eq. (13) the ratio $\left(\alpha_{\text {Bed }}\right)$ of total particle surface area $\left(A_{p}\right)$ to bed volume $\left(V_{\text {Bed }}\right)$ is required to calculate the temperature difference $\left((\Delta T)_{B e d}\right)$ across the interface of particle-fluid in a packed bed. When bed porosity $(\varepsilon)$ is known, total volume of particles contained in a bed column $\left(V_{p}\right)$ can be found from the bed volume.

$V_{p}=(1-\varepsilon) V_{B e d}$

This particle volume can be used to compute total number of particle $(n)$ contained in the bed corresponding to total volume of the particle. 


$$
n=\frac{6 V_{B e d}(1-\varepsilon)}{\pi d_{p}^{2}}
$$

From eq. (14a) total surface area of the spherical particles in the bed $\left(A_{p}\right)$ can be computed. That is

$$
A_{p}=n\left(\pi d_{p}^{2}\right)
$$

From eqs. (14a) and (14b), ratio of the total heat transfer area of the particles to the volume of the bed can be calculated as

$$
\alpha_{\text {Bed }}=\left(\frac{A_{p}}{V_{\text {Bed }}}\right)=\frac{6(1-\varepsilon)}{d_{p}}
$$

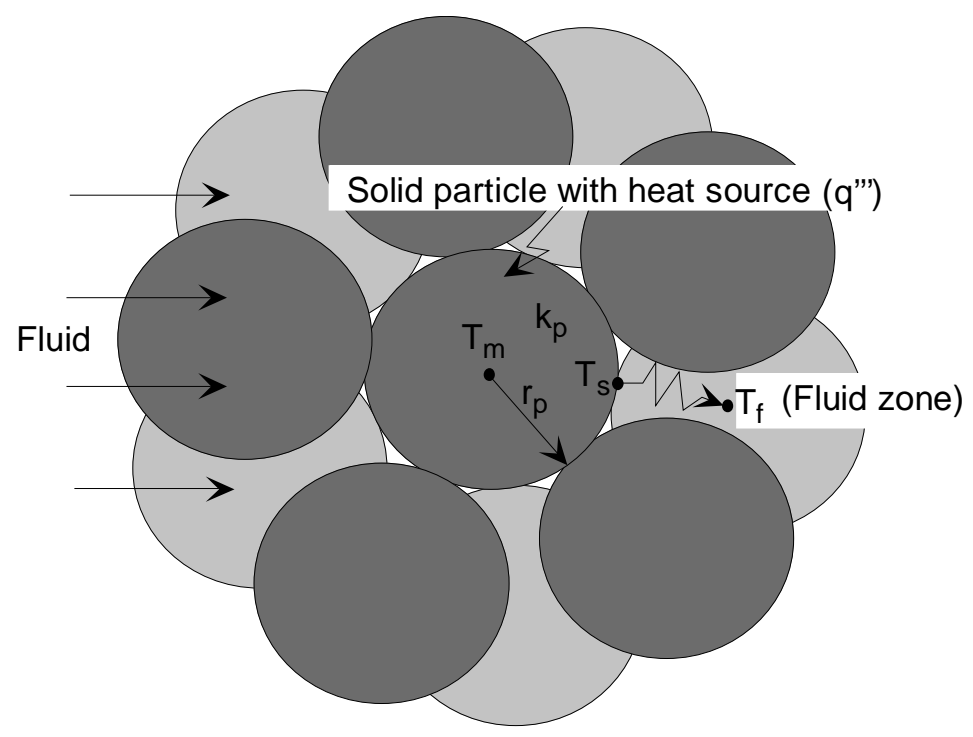

Figure 5. Heat transfer for a fixed porous bed with heat generation source under forced convection cooling condition (Case-III)

\subsubsection{CFD Approach for Heat Transfer Analysis for CST Column (Case-III)}

A computational heat transfer approach was taken to examine multi-dimensional flow distribution effect on fluid and particle surface temperatures and to compare the results with theoretical predictions. For the present analysis, CFX code was used as a computational fluid dynamics (CFD) tool. In the CFD simulations, packed bed is modeled as porous region. The solid portion of the packed bed, which is occupied by the particles, restricts the volume available to the fluid and also offers a resistance resulting in a higher pressure drop. This is modeled by specifying a volume porosity and resistance for the porous region. In the current CFD code, this approach does not 
model the solid portion of the bed, which has heat generation source. The code was modified by user-fortran programs to make energy coupling between fluid and solid cells. A mesh-mapping technique was used to allow energy exchange between the computational cells for the fluid and solid zones.

The main assumptions made regarding the present modeling assessment of heat transfer of the CST column are given as follows:

- The bed is maintained at a steady state with $21 \mathrm{gpm}$ flowrate and is assumed to behave as a volumetrically heated porous medium.

- The bed consists of uniform size and spherical particle.

- There is no flow blockage within the porous flow medium.

- The mean value of bed porosity is equal to the local value in a bed.

- The fractional area of the bed occupied by channeling is assumed to be negligible, which is appropriate for a deep bed (16 ft deep for the CST column)

- Thermal and transport properties of the component materials are assumed to be constant for the present operating conditions.

- Radiation heat transfer is assumed to be negligible compared to convection because of low operation temperature (about $25^{\circ} \mathrm{C}$ ).

The geometry to be modeled here is a cylindrical container of $5 \mathrm{ft}$ diameter as shown in Fig. 6. To model the solid region of the bed, the porous region is duplicated. The duplicated region is placed separated from the main problem as shown in Fig. 6. This region is defined as a conducting solid and is coupled to the fluid passing through the porous region by using user-fortran routines for heat transfer purposes. Threedimensional non-uniform meshes for the computational domain are shown in Fig. 7. A heat transfer coefficient available in the literature was used for the estimation of the particle-to-fluid heat transfer rate. In the calculation, a heat transfer coefficient of 1.36 $\mathrm{W} / \mathrm{m}^{2} \mathrm{~K}$ (equivalent to $\mathrm{Nu}=0.001$ ) was used. Optimum number of computational meshes is about 42,000. Reynolds number for the present analysis is about 0.23 based on the operating conditions shown in Table 2, hence a laminar flow calculation is performed.

For theoretical calculations of the axial heat transfer through a fixed bed, onedimensional integral approach was used assuming that CST particles are homogeneously distributed through a fixed bed and heat is generated uniformly along the flow direction. The heat transfer at the wall of the CST column is assumed to be adiabatic to make one-dimensional approach valid. When there is uniform volumetric heat source (q"') for porous bed as shown in Fig. 8, one-dimensional steady-state integral energy balance along the axial flow z-direction through a bed becomes

$$
A_{\text {Bed }} C_{\rho f} \int_{T_{f}=T_{\text {Tintet }}}^{T_{f}=T_{f}}\left(\rho_{f} u_{f}\right) d T_{f}(z)=q_{\text {Bed }}, ", A_{\text {Bed }} \int_{z=0}^{z=H_{\text {Bed }}} d z
$$

In eq. (15) $A_{B e d}$ and $H_{\text {Bed }}$ are superficial flow area and height of the CST column, respectively. $C_{p f}$ in eq. (15) is specific heat of process fluid. When fluid is assumed to be incompressible, the temperature difference between the exit and the inlet of the bed can be estimated by eq. (15). 


$$
\left(T_{f}(z)-T_{\text {inlet }}\right)=\left(\frac{q^{\prime \prime \prime}}{\rho_{f} u_{\text {avg }} C_{p f}}\right) z
$$

$u_{\text {avg }}$ in eq. (16) represents fluid velocity averaged over the flow area based on empty column at each elevation. That is

$$
u_{\text {avg }}=\frac{1}{A_{\text {Bed }}} \int_{r=0}^{r=R_{\text {Bed }}} 2 \pi r u(r) d r
$$

In eq. (17) local interstitial velocity $v(r)$ is related to superficial velocity $u(r)$ in terms of porosity $\varepsilon$.

$$
v(r)=\left(\frac{u(r)}{\varepsilon}\right)
$$

For an incompressible flow with constant flow area, average superficial velocity $\left(u_{\text {avg }}\right)$ under steady-state flow condition is constant along the z-direction shown in Fig. 8. For given particle size and volumetric heat source, maximum particle temperature at the exit of the CST column can be obtained in terms of fluid velocity and heat transfer coefficient. After some algebraic rearrangements of eqs. (4a), (13), and (16), maximum particle temperature at the exit of the column becomes

$$
\begin{aligned}
\left\{T_{m}-T_{\text {inlet }}\right\}_{\text {exit }} & =\left(T_{m}-T_{s}\right)_{\text {exit }}+\left(T_{s}-T_{f}\right)_{\text {exit }}+\left\{T\left(z=H_{\text {Bed }}\right)-T_{\text {inlet }}\right\} \\
& \approx\left(\frac{d_{p}{ }^{2}}{24 k_{p}(1-\varepsilon)}+\frac{d_{p}}{6 h_{f}(1-\varepsilon)}+\frac{H_{\text {Bed }}}{\rho_{f} u_{\text {avg }} C_{p f}}\right) q_{\text {Bed }},,
\end{aligned}
$$

The above equation for maximum bed temperature is based on a one-dimensional concept. It shows that maximum particle temperature occurs at the exit plane of the column. Note that maximum temperature of the CST bed increases because of the reduced convection energy transport as process fluid velocity of the column decreases during normal operating conditions. 

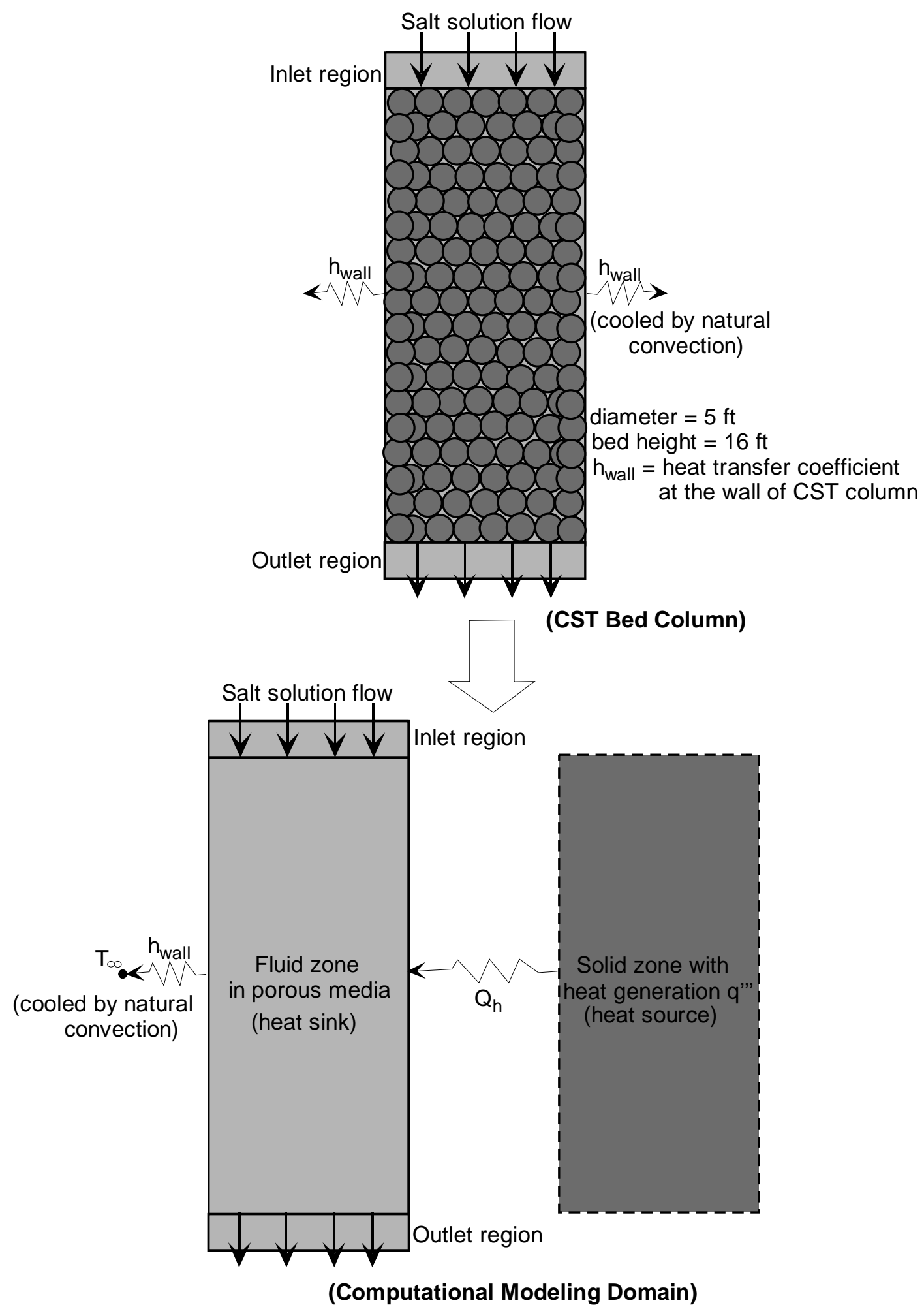

Figure 6. Computational model for the heat transfer in CST column using CFD approach. 
Report: WSRC-TR-2001-00255

Date: $\quad 07 / 24 / 01$

Page: $\quad 14$ of 24
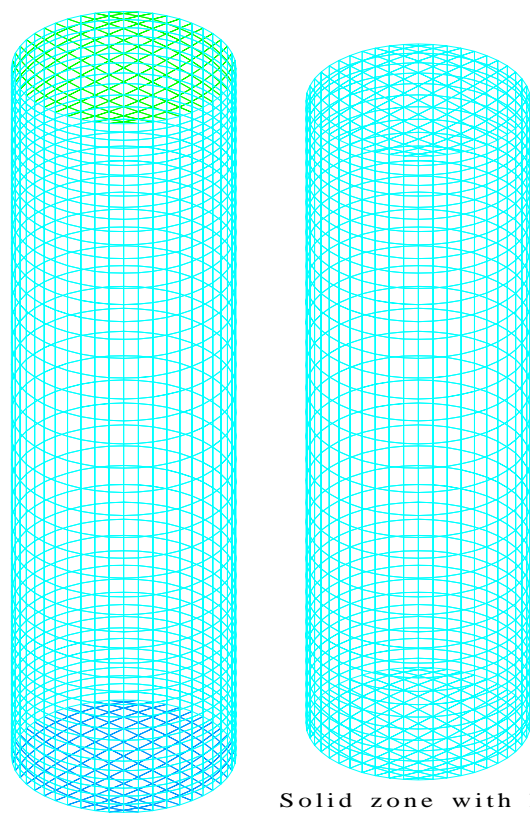

Solid zone with heat generation source

Fluid zone in porous domain

Figure 7. Computational meshes for the CST heat transfer calculations 


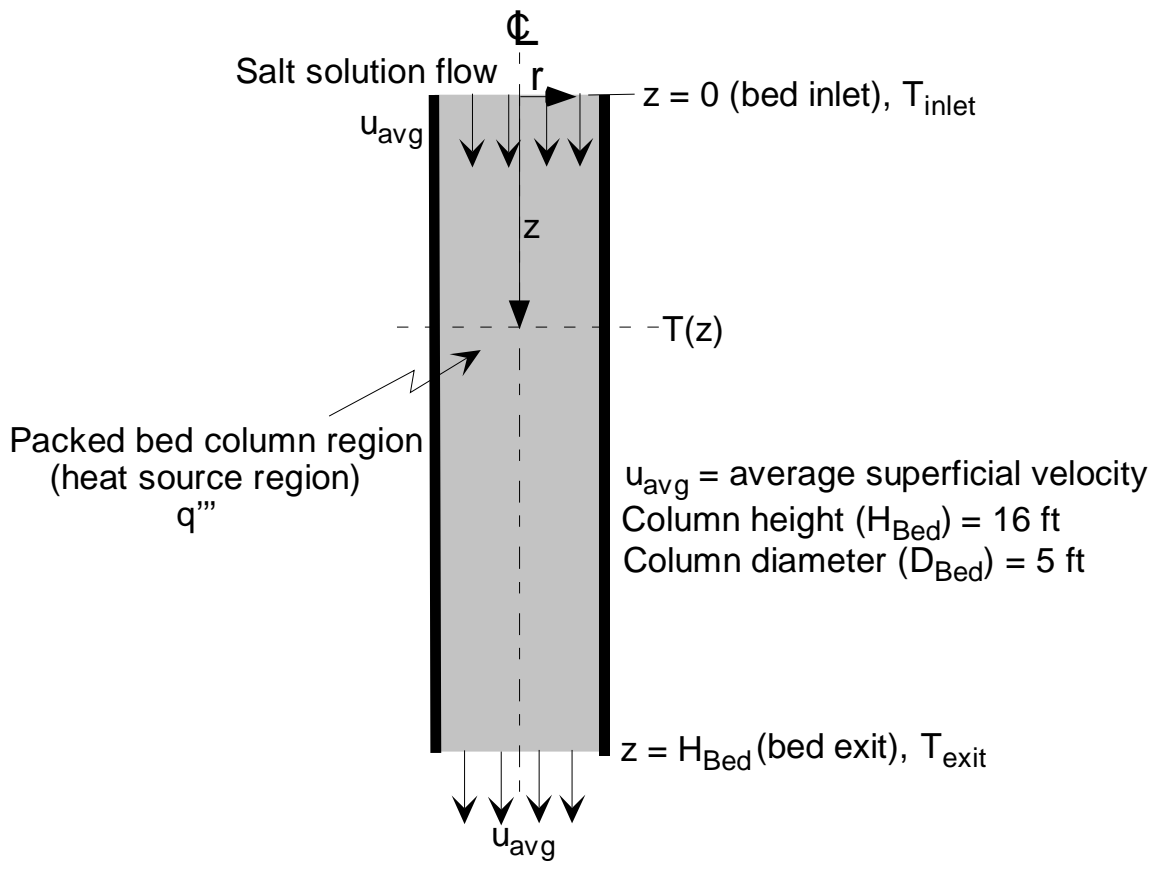

Figure 8. Theoretical approach of one-dimensional energy transport for the CST column with adiabatic wall boundary.

\section{Results and Discussions}

Based on the approach methodology and the modeling assumptions, theoretical and CFD analyses have been performed to compute temperature distributions within the CST modeling domain and to investigate steady-state temperature response to decay heat load of the CST column with normal process flow. This column is assumed to be cooled by natural convection or adiabatic wall boundary under the reference design conditions defined by Table 2. For natural convection boundary, heat transfer coefficient of $1.5 \mathrm{~W} / \mathrm{m}^{2} \mathrm{~K}$ was used as discussed in the previous works [Refs. 1, 6, 9, and 15]. The thermal and material properties of the column components including the CST particle are shown in Table 4. Detailed dimensions for the CST design configurations are shown in Fig. 1 and Table 2 as modeled in the present analysis.

For the present analysis, three basic cases were theoretically considered to estimate sensitivities of temperature distributions with respect to the configurations of fluidparticle systems in a bed column. Steady-state temperature responses to uniform volumetric heat source in a fixed porous bed were estimated using the literature data. In the theoretical approach, one-dimensional approach was taken by considering overall energy balance equation for the CST column with adiabatic wall boundary condition.

The computational heat transfer approach was also taken to estimate detailed flow distribution effect on the temperature profiles for the column. In this approach, a commercial CFD code, CFX [4], was used to create prototypic geometry file under nonorthogonal mesh environment in the body-fitted coordinate system and to solve the heat transfer equations by considering conduction-convection coupled process with natural convection or adiabatic boundary conditions at the wall of the CST column. As 
mentioned in the previous section, a node-mapping technique was developed to consider convection effect in the energy equation due to the fluid motion within porous media when heat source is present in solid particle region. Through the mapping algorithm, energy exchange between the solid region with heat source and the fluid region with heat sink was allowed to consider the conduction-convection coupled process in porous media. The detailed descriptions of the governing equations for the computational domain are provided in the previous report [Ref. 1]. Optimum number of meshes was obtained by the sensitivity analysis of grid fineness using the same method as the previous one. Figure 7 presents three-dimensional computational meshes for porous flow and solid zones used for the present analysis.

A theoretical approach for steady-state convection heat transfer of a fully-loaded CST column with uniform volumetric heat source was taken to compare the present computational results under the present geometrical and physical conditions as shown in Fig. 8. The results are summarized in Table 5. It is noted that there is negligible temperature difference between the center and surface of spherical particle for each of the 500 and 700 micron particles for all the cases considered here because the temperature difference is only related to the particle size and thermal property of the particle for a given heat source as shown in eq. (4a). Heat transfer for single particle surface to fluid is found to be much higher than that of a packed bed from the experimental data available in the literature as shown in Table 5.

Heat removal capability of salt solution in CST column was evaluated under $21 \mathrm{gpm}$ normal flow conditions. Figure 9 shows velocity vector plot of salt solution flow for uniform porous medium of the CST column with constant volumetric heat source. Temperature contour plots for the fluid and solid zones of the CST column are shown in Fig. 10. The results show that temperature near the wall boundary is higher than that of the central region of the column because of the velocity boundary layer near the no-slip wall region as shown in Fig. 11. Figure 12 presents radial temperature distributions for fluid and solid regions at the exit plane of the CST column for natural convection boundary at the column wall. These results are consistent with the theoretical results predicted by eq. (19) for constant volumetric heat source of the bed. Figure 13 illustrates qualitative results for some key operation parameters of the CST column. Average temperature difference between the solid surface and the bulk fluid region in a fixed bed is shown to be about $0.34{ }^{\circ} \mathrm{C}$ as shown in Table 5. Figure 14 shows comparison of the theoretical predictions for fluid temperature with the model results along the axial flow direction. In Fig. 14, the CFD model results are based on the values averaged over the cross-sectional area of the column. The results show that about $5{ }^{\circ} \mathrm{C}$ fluid temperature increases through the bed column for the present conditions shown in Table 2 and Table 4 . Table 6 shows the comparison of the theoretical results with the CFD model predictions. It is noted that the CFD model prediction is about $0.2{ }^{\circ} \mathrm{C}$ lower than the theoretical prediction when natural convection boundary condition is applied to the wall of the column.

The simulation results for the packed bed (Case-III) show that about $34^{\circ} \mathrm{C}$ maximum temperature of the CST particle was reached near the wall boundary layer of the CST column for normal operating conditions and salt solution temperature is about $1^{\circ} \mathrm{C}$ lower than the particle temperature for the present design and operating conditions of the CST column. In the present model, boundary condition of heat transfer at the wall of the CST column was assumed to be adiabatic or cooled by natural convection. Table 7 
summarizes maximum temperatures for process solution and CST particle for the present normal operations of a fully-loaded CST column. In this case, porosity was assumed to be uniform over the entire region of the column. In reality, the packing near the wall is usually less dense, which is closely related to the ratio of the particle diameter to the column diameter. For the present design conditions, this ratio is very large, about 3,048 for 500 -micron particle, so that porosity change due to the presence of the column wall is negligible.

Table 5. Summary for the heat transfer calculation results for the three cases considered in the analysis.

\begin{tabular}{|l|c|c|c|c|c|}
\hline \multirow{2}{*}{ Cases } & \multicolumn{5}{|c|}{ Calculation Reults } \\
\cline { 2 - 3 } & \multicolumn{2}{|c|}{$\left(\mathrm{T}_{\mathrm{m}}-\mathrm{T}_{\mathrm{s}}\right)_{\text {theory }}{ }^{+}$} & \multirow{2}{*}{$\begin{array}{c}\text { Nusselt } \\
\text { No. }\end{array}$} & \multicolumn{2}{|c|}{ Average temperature difference } \\
\cline { 2 - 3 } \cline { 5 - 6 } & 500 microns & 700 microns & $\left(\mathrm{T}_{\mathrm{s}}-\mathrm{T}_{\mathrm{f}}\right)_{\text {theory }}{ }^{* *}$ & $\left(\mathrm{~T}_{\mathrm{s}}-\mathrm{T}_{\mathrm{f}}\right)_{\text {CFD-model }}$ \\
\hline Case-I & $0.0004^{\circ} \mathrm{C}$ & $0.0007^{\circ} \mathrm{C}$ & 2.0 & $0.0002^{\circ} \mathrm{C}$ & --- \\
\hline Case-II & $0.0004^{\circ} \mathrm{C}$ & $0.0007^{\circ} \mathrm{C}$ & $4.51^{*}$ & $0.00008^{\circ} \mathrm{C}$ & --- \\
\hline Case-III & $0.0004^{\circ} \mathrm{C}$ & $0.0007^{\circ} \mathrm{C}$ & $0.001^{*}$ & $0.34^{\circ} \mathrm{C}$ & $0.34^{\circ} \mathrm{C}$ \\
\hline
\end{tabular}

Note: ${ }^{*}$ Nusselt number $\left(\mathrm{Nu}=\left(d_{p} h_{f}\right) / k_{f}\right)$ was evaluated by the literature correlation for nominal operating conditions $(\mathrm{Re} \approx 0.23)$.

** Temperature difference was evaluated by the heat transfer correlations available in the literature

+ Calculated by Eq. (4a)

Table 6. Comparison of the one-dimensional theoretical predictions with the CFD model results for heat removal capability of the CST column.

\begin{tabular}{|c|c|c|c|}
\hline \multirow{2}{*}{ Parameters } & \multicolumn{3}{|c|}{ Average axial fluid temperature differences } \\
\cline { 2 - 4 } & Theoretical predictions* & \multicolumn{2}{|c|}{ CFD Model predictions } \\
\cline { 2 - 4 } & $4.89^{\circ} \mathrm{C}$ & $\begin{array}{c}\text { Adiabatic wall } \\
\text { boundary }\end{array}$ & $\begin{array}{c}\text { Natural convection } \\
\text { wall boundary }\end{array}$ \\
\hline$\left(\mathrm{T}_{\text {exit }}-\mathrm{T}_{\text {inlet }}\right)$ CST-column & $4.91^{\circ} \mathrm{C}$ & $4.68^{\circ} \mathrm{C}$ \\
\hline
\end{tabular}

Note: * Adiabatic boundary was assumed at the wall of the CST column based on onedimensional approach.

Table 7. Comparison of maximum temperatures predicted by the CFD model of the CST column.

\begin{tabular}{|l|c|c|c|c|}
\hline \multirow{2}{*}{ Items } & \multicolumn{4}{|c|}{ Max. temperatures } \\
\cline { 2 - 5 } & \multicolumn{2}{|c|}{$\begin{array}{c}\text { Natural Convection at the } \\
\text { Column Wall }\end{array}$} & \multicolumn{2}{c|}{$\begin{array}{c}\text { Adiabatic Condition at the } \\
\text { Column Wall }\end{array}$} \\
\hline & Salt solution & CST particle & Salt solution & CST particle \\
\hline Inlet of the CST column & $25^{\circ} \mathrm{C}$ & $25{ }^{\circ} \mathrm{C}$ & $25^{\circ} \mathrm{C}$ & $25^{\circ} \mathrm{C}$ \\
\hline Exit of the CST column & $32.3^{\circ} \mathrm{C}$ & $33.6^{\circ} \mathrm{C}$ & $32.9^{\circ} \mathrm{C}$ & $34.0^{\circ} \mathrm{C}$ \\
\hline
\end{tabular}




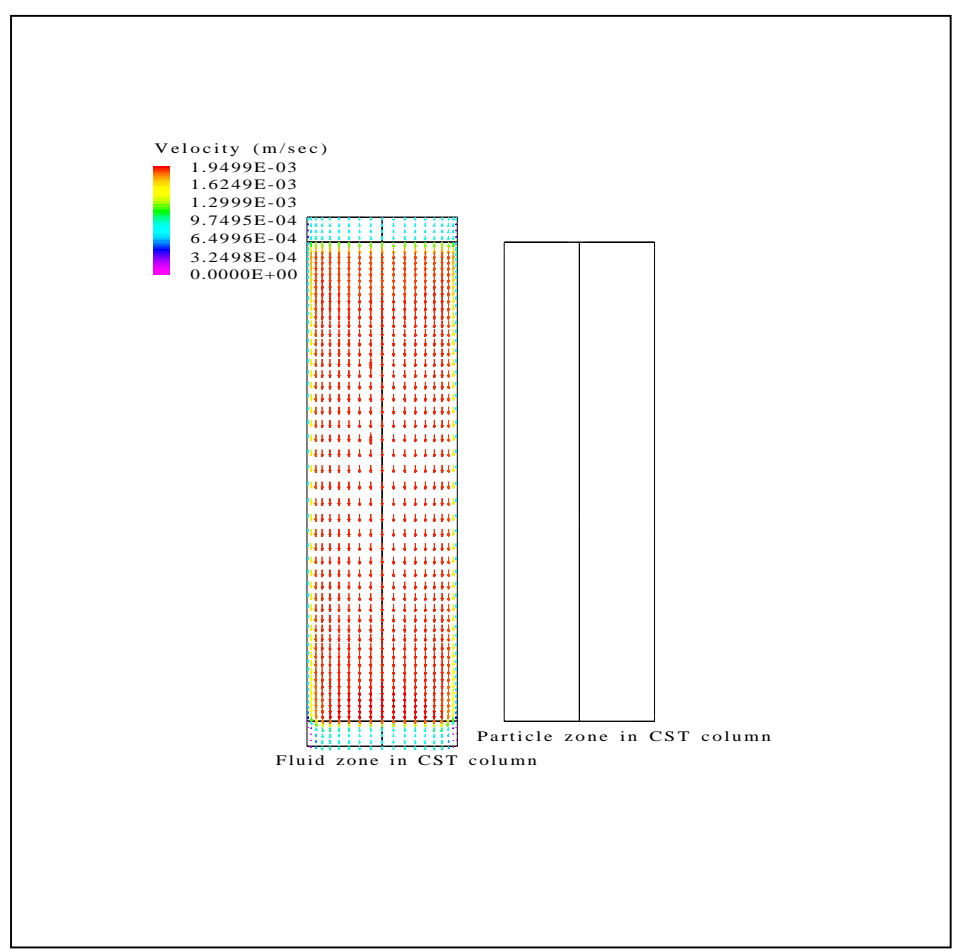

Figure 9. Fluid velocity vector plot in the porous region of the CST column

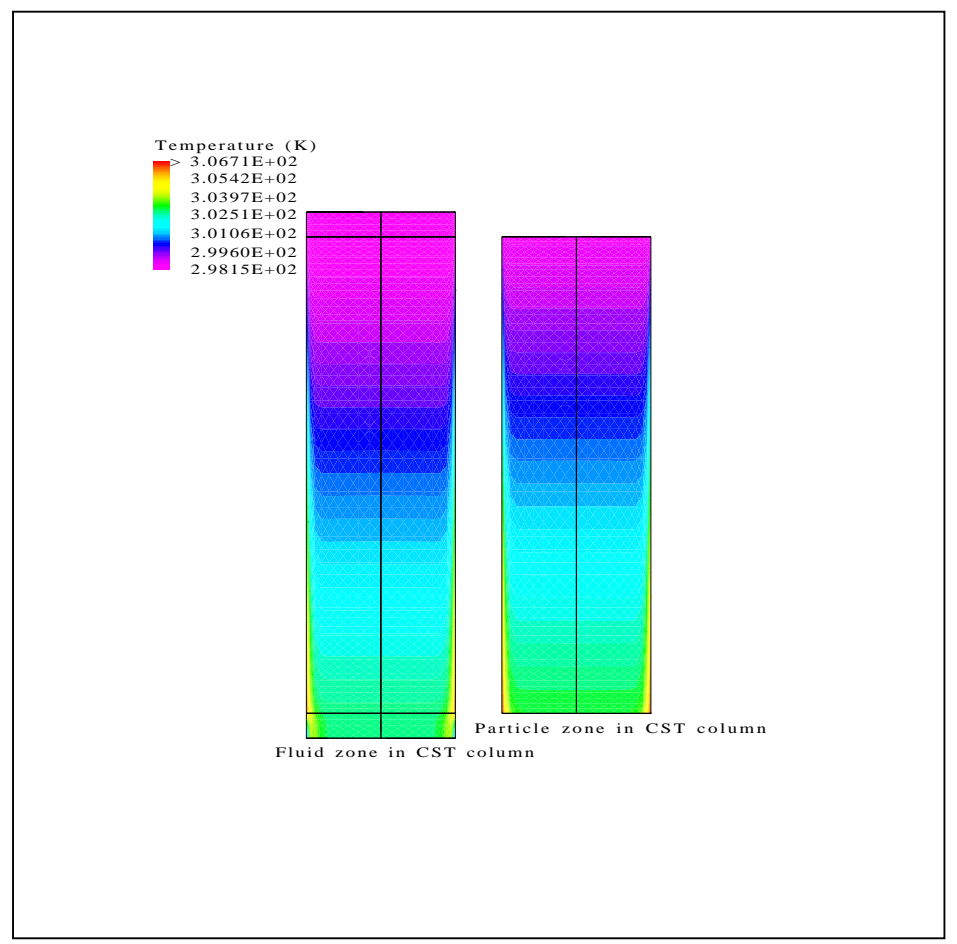

Figure 10. Temperature contour plots for the fluid and solid particle zones of the CST column cooled by natural convection at the wall 


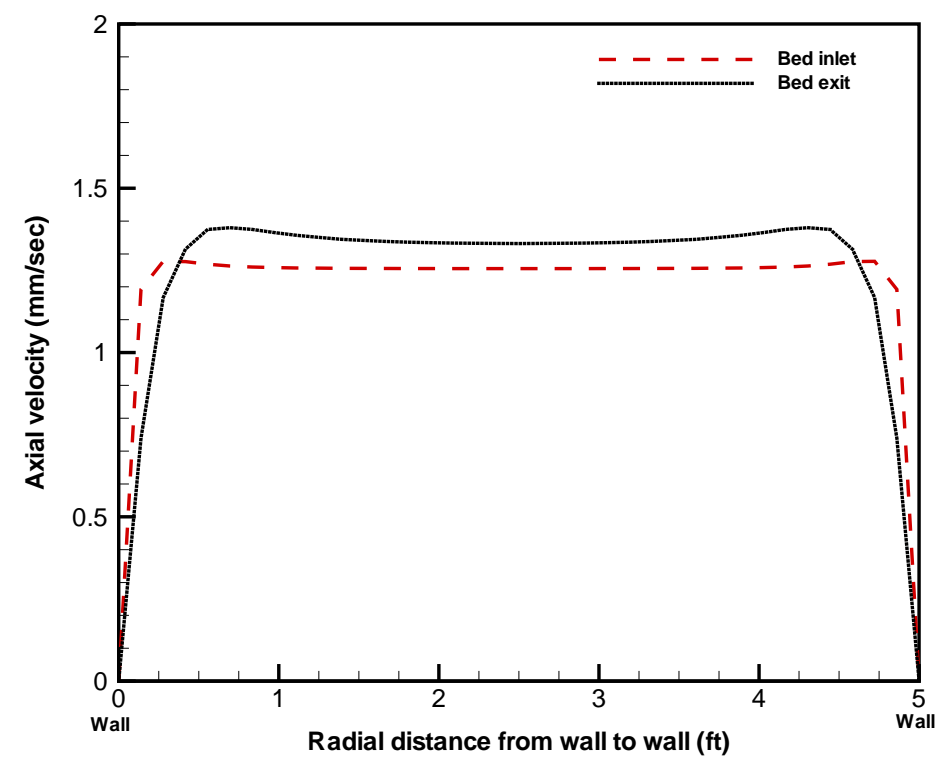

Figure 11. Radial interstitial velocity distributions at inlet and exit planes of the CST column

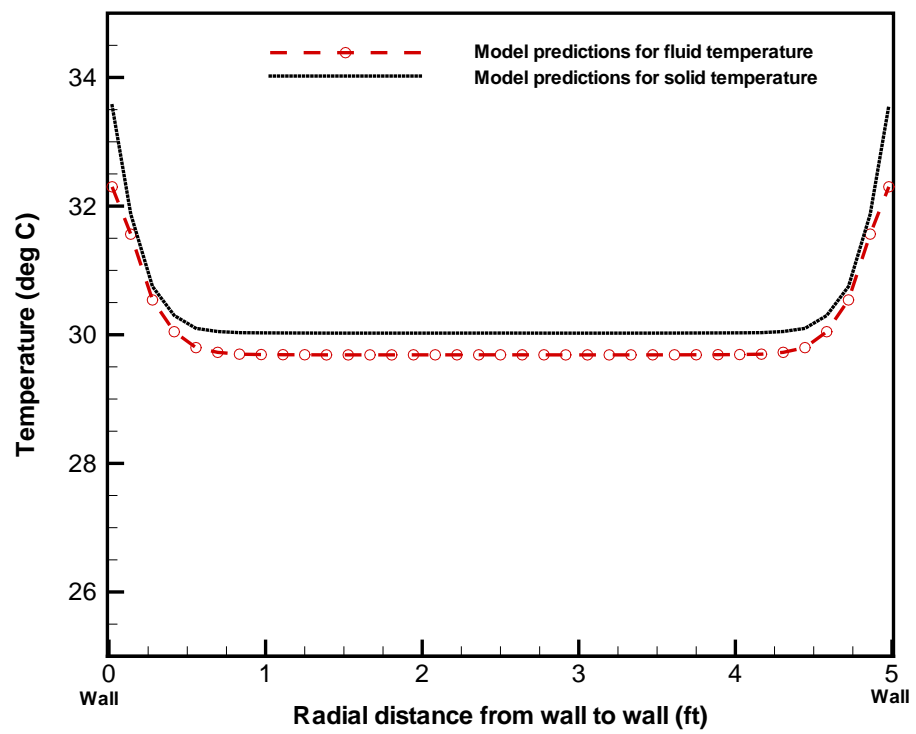

Figure 12. Comparison of radial temperature distributions for fluid and solid at the exit of the CST column for natural convection boundary conditions at the bed column wall 


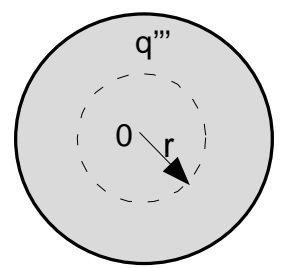

(Cross-sectional area of a fully-loaded CST column)

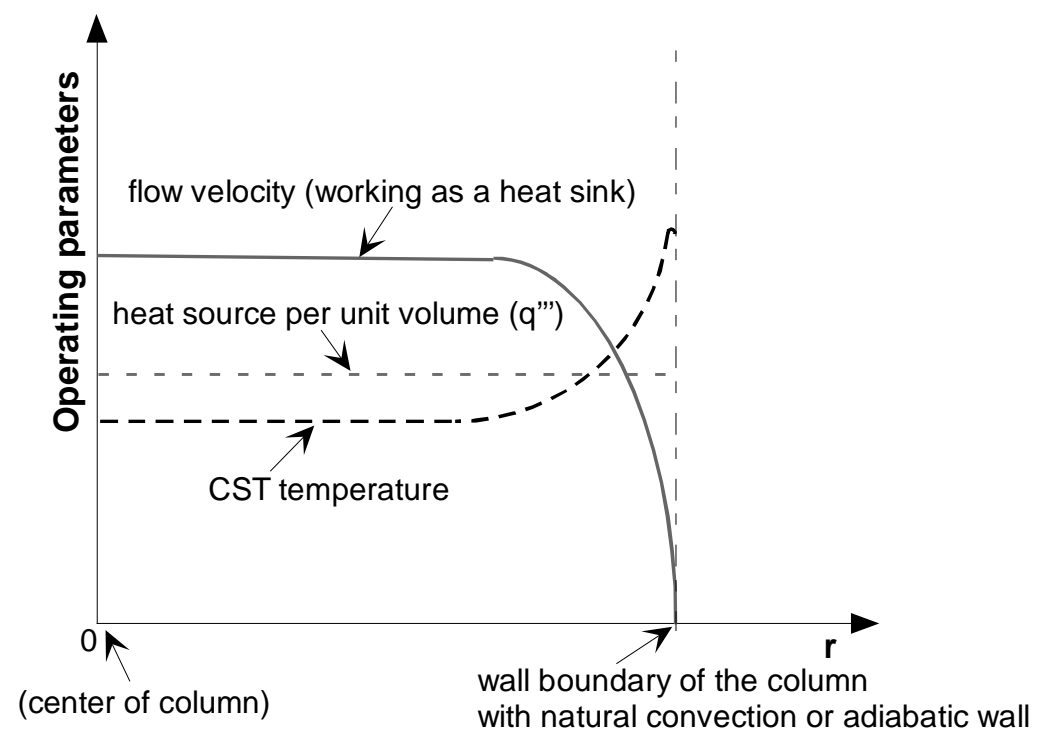

Figure 13. Qualitative results of key operating parameters as function of radial position at the exit of the CST column with uniform volumetric heat source 


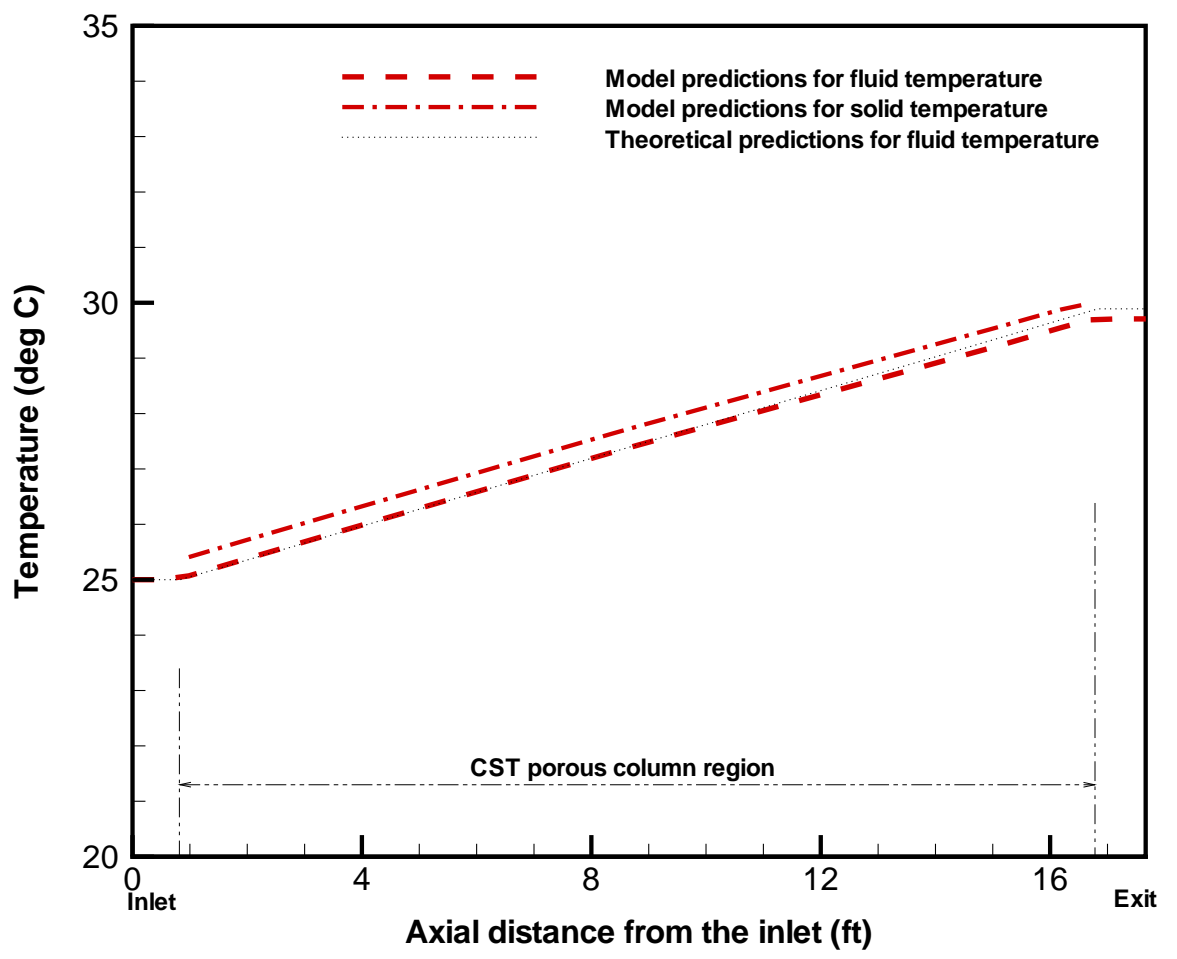

Figure 14. Comparison of axial temperature distributions along the flow direction

\section{Conclusions}

Heat transfer calculations for normal operating conditions of a fixed bed CST ion exchange column have been performed to assess how high the CST ion exchange system heats up during steady and downward flow operation under the reference design geometry. In the present analysis, radiation transport processes inside the CST column were assumed to be negligible compared to conduction and convection heat transfers under normal flow conditions. A boundary condition of heat transfer at the wall of the CST column was assumed to be adiabatic or cooled by natural convection.

Both theoretical and computational approaches were taken for the present work. As theoretical approach, three different configurations of fluid-particle system were considered to find the sensitivity of heat transfer capabilities with respect to operating parameters such as fluid velocity and particle packing type. For a cylindrical packed bed column under normal operating conditions (Case-III), a computational heat transfer approach was taken by using CFX, commercial computational fluid dynamics (CFD) code, to examine the multi-dimensional effect of fluid motion on the heat transfer of the column. In addition, the results computed by the present models were verified by the theoretical results. In the computational models, constant volumetric heat source for the 
column was considered assuming that non-uniform local effects on the heat generation of the CST particles are negligible.

All the analysis results demonstrate that process fluid flow of the normal operating CST column provides adequate heat removal from a fully-loaded fixed bed column. Theoretical temperature distributions inside a single solid particle with uniform heat generation source indicate that the present CST particle has negligible temperature difference between the center and surface of the spherical particle containing heat source. The Case-I model investigated temperature drop across the interface of the particle-fluid for a single particle submerged in stagnant fluid system due to natural convection cooling. The Case-II model quantified temperature difference between the particle surface and its surrounding bulk fluid for the fluid-particle system with flow conditions and compared with the Case-I. The Case-III model simulated a fixed porous bed, which is close to the present CST bed column with volumetric heat source.

As expected, the results of the three models show that closely-packed bed configuration is much less coolable than dilute or loosely packed bed is. The CFD simulation results for a fully-loaded CST column show that about $34^{\circ} \mathrm{C}$ maximum temperature of the CST particle was reached at the wall boundary layer of the CST column when the column has $21 \mathrm{gpm}$ steady flow with $25^{\circ} \mathrm{C}$ inlet temperature for normal operating conditions and the column wall is cooled by natural convection. In this case the salt solution temperature is about $1^{\circ} \mathrm{C}$ lower than the particle temperature for the present operation conditions of the CST column.

From the present analysis results, main conclusions are drawn as follows:

- Under the present design and normal flow operations, the temperature difference between the CST particle and its surrounding bulk fluid is found to be less than $0.5^{\circ} \mathrm{C}$.

- The coolability of the packed column containing volumetric heat source under process flow condition is much higher than the CST column with no flow.

- The impact of natural convection cooling through a fully-loaded column wall on the CST component temperatures is found to be negligible, compared to the heat removal made by forced convection during the normal operations of the present CST column system.

- From the sensitivity study of the CST column parameters, it was found that packing such as loosely or closely packed column is a key design parameter associated with the coolability of a fully-loaded CST column under flow condition since volume fraction of flowing fluid in the column, bed porosity, is closely related to the effective energy transport of the CST bed. 


\section{References}

1. S. Y. Lee, "Heat Transfer Calculations For a Fixed CST Bed Column", WSRC-TR2000-00522, December 2000.

2. J. A. Pike, "Interoffice Memorandum: Input for Heat Transfer Calculations for Normal Operations of a Fixed Bed CST Ion Exchange Column", HLW-SDT-200100100, Rev. 0, March 20, 2001.

3. B. B. Spencer, H. Wang, K. K. Anderson, "Thermal Conductivity of IONSIVIE911TM Crystalline Silicotitanate and Savannah River Waste Simulant Solutions", ORNL/TM-2000/285, Oah Ridge National Laboratory, TN, 2000.

4. CFX-4.2: Environment, AEA Technology (1997).

5. D. T. Bostick and W. V. Steele, "Thermal and Physical Property Determination for IonsivIE-911 Crystalline Silicotitanate and Savannah River Waste Simulant Solutions", WSRC-TR-99-00323, Rev. 0 (August 1999).

6. S. Y. Lee, "Three-Dimensional Thermal Analysis and Simulation of Dry Spent Nuclear Fuel Storage Canister Using CFDS-FLOW3D (U)", WSRC-TR-96-0059 (March 1996).

7. W. M. Kays and M. E. Crawford, Convective Heat and Mass Transfer, Second Edition, McGraw-Hill Book Company, New York (1980).

8. A. J. Chapman, Heat Transfer, Third Edition, Macmillan Publishing Co., Inc,, (1974).

9. C. Y. Warner and V. S. Arpaci, "An Experimental Investigation of Turbulent Natural Convection in Air at Low Pressure along a Vertical Heated Flat Plate", International Journal of Heat and Mass Transfer, Vol. 11, pp. 397-406 (1968).

10. Personal Communications with J. A. Pike, March 21, 2001

11. R. Rudenberg, "The Spread of Air and Ground Fields for High Voltage Conductance Especially with Ground Connections and Short Circuits", Elektrotech. Z., Vol. 46, pp. 1342-1346 (1925).

12. H. Kramers, Physica, Vol. 12, pp. 61 (1946).

13. F. A. Zenz and D. F. Othmer, Fluidization and Fluid-Particle Systems, Reinhold Publishing Corp., New York, 1960.

14. D. J. Gunn and J. F. C. De Souza, "Heat Transfer and Axial Dispersion in Packed Beds", Chemical ngineering Science, Vol. 29, pp. 1363-1371, 1974.

15. J. Jerrell, S. Y. Lee, and A. Shadday, "Thermal Analysis of the Failed Equipment Storage Vault System (U)", WSRC-TR-95-0288 (1995).

16. R. Krupiczka, "Analysis of Thermal Conductivity in Granular Materials", International Chemical Engineering, Vol. 7, No. 1, pp. 122-144 (1967).

17. W. M. Rohsenow and H. Y. Choi, Heat, Mass, and Momentum Transfer, PrenticeHall, Inc., New Jersey (1961).

18. Schack, A., Industrial Heat Transfer, Wiley, New York (1965). 
Report: WSRC-TR-2001-00255

Date: $\quad 07 / 24 / 01$

Page: $\quad 24$ of 24
WESTINGHOUSE SAVANNAH RIVER COMPANY

HEAT TRANSFER CALCULATIONS FOR NORMAL

OPERATIONS OF A FIXED CST BED COLUMN

(This Page Intentionally Left Blank) 